\title{
The plasma clearance of injected doses of folic acid as an index of folic acid deficiency
}

\author{
J. METZ, K. STEVENS, S. KRAWITZ, AND V. BRANDT \\ From the Nuffield Nutritional Anaemia Unit, South African \\ Institute for Medical Research, Johannesburg
}

SYNOPSIS The folic acid clearance test of Chanarin (1958) has been studied in normal white subjects, patients with megaloblastic anaemia, healthy Bantu males, Bantu females, hospital patients without anaemia, and in patients with scurvy.

The test clearly distinguishes patients with megaloblastic anaemia, where clearance from the plasma of injected folic acid is abnormally rapid, from normal subjects. The rate of clearance of folic acid is abnormally rapid both in vitamin $B_{12}$ and in folic acid deficiency. Rapid clearance of injected folic acid in patients with primary $\mathbf{B}_{12}$ deficiency may be the result of a conditioned deficiency of folic acid.

The test is sufficiently sensitive to detect body deficiency of folic acid before the development of anaemia.

In patients with scurvy, folic acid is cleared from the plasma abnormally rapidly. It is suggested that this may be the result of an associated dietary deficiency of folic acid.

While the assay of vitamin $B_{12}$ in serum provides a sensitive and specific index of body deficiency of that vitamin, there is no generally accepted parallel procedure for the diagnosis of folic acid deficiency. The recognition that deficiency of vitamin $B_{12}$ may precede the development of anaemia by a considerable period (Callender and Denborough, 1957) makes the development of a sensitive test for body deficiency of folic acid necessary.

Attempts have been made to develop specific and sensitive procedures for the diagnosis of folic acid deficiency. Spray, Fourman, and Witts (1951) injected small doses of folic acid and measured the amount excreted in the urine. Patients with folic acid deficiency excreted less of the injected dose than did control subjects. The test is of limited sensitivity and the small volume of urine assayed greatly multiplies any technical errors.

Assay of folic acid in fasting serum with $L$. casei has been claimed by Herbert, Baker, Frank, Pasher, Sobotka, and Wasserman (1960) to delineate megaloblastic anaemias due to primary folic acid deficiency from those with vitamin $\mathbf{B}_{12}$ deficiency, but Cooperman, Luhby, and Avery (1960) found the overlap among normal and folic acid deficiency so great that the determination was of no value as an index of folic acid deficiency.

Received for publication 5 April 1961
Formiminoglutamic acid (FIGLU), an intermediate in the metabolism of histidine, accumulates in the urine in subjects with folic acid deficiency (Broquist, 1956; Luhby, 1957; Silverman, Gardiner, and Condit, 1958; Broquist and Luhby, 1959; Spray and Witts, 1959). However, there appears to be some doubt as to the sensitivity of the methods for its detection. Davidson and Jandl (1959) state that the presence of FIGLU in the urine does not appear to be an entirely satisfactory test for folic acid deficiency at present, and Herbert et al. (1960) do not consider the method dependable for detecting folic acid deficiency.

Chanarin, Mollin, and Anderson (1958a) injected intravenously a standard dose of folic acid and measured its rate of clearance from the plasma. In all patients with megaloblastic anaemia due to folic acid deficiency and in nine of 20 patients with megaloblastic anaemia due to vitamin $\mathbf{B}_{12}$ deficiency, the clearance of the injected folic acid was more rapid than in control subjects. Chanarin, MacGibbon, O'Sullivan, and Mollin (1959) subsequently studied 250 non-anaemic pregnant females, 11 patients with normal twin pregnancy, and 11 patients with untreated megaloblastic anaemia of pregnancy. The plasma clearance of folic acid was abnormally rapid in two-thirds of pregnant subjects in late pregnancy, and in all patients with twin pregnancy. 
The rate of clearance was most rapid in patients with megaloblastic anaemia of pregnancy. Although the test did not distinguish between deficiency of vitamin $B_{12}$ and folic acid, it was invariably abnormal in megaloblastic anaemias due to folic acid deficiency, and was sufficiently sensitive to detect body deficiency of folic acid before the development of anaemia.

In the South African Bantu, megaloblastic anaemias are commonly encountered, particularly in association with pregnancy, and in malnourished infants (Metz, 1960). In these patients, serum vitamin $B_{12}$ levels may be subnormal but are not usually as low as in patients with pernicious anaemia. Folic acid therapy invariably induces haematological remission, while the results of pharmacological doses of vitamin $B_{12}$ are uncertain (Metz, 1960). With a high incidence of malnutrition in this ethnic group, there is possibly a great deal of subclinical folic acid deficiency. The folic acid clearance test of Chanarin appears to be a promising index of folic acid deficiency; this paper presents then the results of the application of this test in groups of normal subjects, Bantu and white patients with megaloblastic anaemia, and Bantu subjects not suffering from anaemia.

\section{METHODS}

The folic acid clearance test was carried out as described by Chanarin et al. (1958a). A dose of $15 \mu \mathrm{g}$. folic acid per kg. body weight was injected intravenously, and blood drawn at three, 15, and 30 minutes later. The serum was separated and stored at $-20^{\circ} \mathrm{C}$. until assayed. Serum folic acid was assayed microbiologically with Str. faecalis as described by Jukes (1955) and Chanarin, Anderson, and Mollin (1958b). Standard sera were included in each assay. Each specimen was assayed in triplicate in at least two, and usually in three, separate batches.

Serum vitamin $\mathrm{B}_{12}$ was assayed with $L$. leishmanii as described previously (Brandt and Metz, 1961). Normal values range from 160 to $1,300 \mu \mu \mathrm{g} . / \mathrm{ml}$.

\section{SUBJECTS STUDIED}

NORMAL WHITES Thirteen female and 19 male White laboratory staff or medical students who were not anaemic.

MEGALOBLASTIC ANAEMIA ASSOCIATED WITH PREGNANCY Twenty-one patients with megaloblastic anaemia, comprising 19 Bantu presenting after delivery, and two Whites in the last trimester of pregnancy.

PERnicious ANAEMIA Twelve Whites and three Bantu patients with megaloblastic anaemia and subnormal serum vitamin $\mathbf{B}_{12}$ levels. Vitamin $\mathbf{B}_{12}$ by intramuscular injection induced complete haematological remission in all.

SCURVY Three Bantu adults with the classical clinical features of scurvy.
BANTU MALES Eight members of staff not suffering from anaemia.

BANTU FEMALES Eight hospital patients who were not anaemic convalescing from diseases not usually affecting folic acid metabolism.

\section{RESULTS}

NORMAL WHITES The differences in the mean folic acid levels in male and female subjects are not statistically significant (Table I). The mean levels at three, 15, and 30 minutes after the intravenous

TABLE I

\begin{tabular}{|c|c|c|c|c|c|c|}
\hline \multirow{3}{*}{$\begin{array}{l}\text { SER } \\
\text { No. }\end{array}$} & \multirow{2}{*}{\multicolumn{3}{|c|}{$\begin{array}{l}\text { M FOLIC ACID IN NORMAL } \\
\text { Males } \\
\text { Folic Acid ( } \mu \mathrm{mg} . / \mathrm{ml} \text {.) }\end{array}$}} & \multirow{2}{*}{\multicolumn{3}{|c|}{$\begin{array}{l}\text { MALES AND FEMALES } \\
\text { Females } \\
\text { Folic Acid (umg./ml.) }\end{array}$}} \\
\hline & & & & & & \\
\hline & 3 Min. & 15 Min. & 30 Min. & 3 Min. & 15 Min. & 30 Min. \\
\hline 1 & 87 & 27 & 8 & 96 & 52 & 14 \\
\hline 2 & 91 & 52 & 25 & 122 & 22 & 12 \\
\hline 3 & 94 & 35 & 19 & 128 & 58 & 24 \\
\hline 4 & 110 & 20 & 20 & 144 & 48 & 13 \\
\hline 5 & 118 & 43 & 9 & 148 & 45 & 16 \\
\hline 6 & 128 & 91 & 12 & 154 & 54 & 22 \\
\hline 7 & 130 & 27 & 20 & 158 & 46 & 15 \\
\hline 8 & 134 & 53 & 35 & 160 & 60 & 24 \\
\hline 9 & 138 & 38 & 19 & 163 & 54 & 29 \\
\hline 10 & 140 & 45 & 38 & 164 & 42 & 16 \\
\hline 11 & 142 & 75 & 21 & 168 & 62 & 36 \\
\hline 12 & 148 & 55 & 28 & 173 & 61 & 33 \\
\hline 13 & 154 & 50 & 17 & 180 & 62 & 43 \\
\hline 14 & 170 & 49 & 39 & & & \\
\hline 15 & 174 & 25 & 11 & & & \\
\hline 16 & 178 & 29 & 9 & & & \\
\hline 17 & 182 & 60 & 25 & & & \\
\hline 18 & 190 & 46 & 24 & & & \\
\hline 19 & 219 & 73 & 24 & & & \\
\hline 20 & 220 & 65 & 27 & & & \\
\hline 21 & 260 & 49 & 30 & & & \\
\hline $\begin{array}{l}\text { Mean } \\
\text { S.D. }\end{array}$ & $\begin{array}{c}152.7 \\
44\end{array}$ & $\begin{array}{l}47 \cdot 9 \\
17\end{array}$ & $\begin{array}{r}21.9 \\
8.8\end{array}$ & $\begin{array}{c}150.6 \\
22\end{array}$ & $\begin{array}{l}51 \cdot 2 \\
11\end{array}$ & $\begin{array}{r}22.8 \\
9.6\end{array}$ \\
\hline
\end{tabular}

injection of folic acid are slightly higher than those reported by Chanarin et al. (1958a) but the ranges at 15 and 30 minutes in the two studies are similar. The lower limit at three minutes is similar in the two series but in the present study the upper limit at three minutes is higher than that of Chanarin $e t$ al. (1958a). We confirm the observations of Chanarin that after the intravenous injection of a dose of $15 \mu \mathrm{g}$. folic acid per kg. body weight, serum folic acid levels of less than $75 \mu \mathrm{mg}$./ml. at three minutes, $26 \mu \mathrm{mg}$./ $\mathrm{ml}$. at 15 minutes, and $4 \mu \mathrm{mg}$. $/ \mathrm{ml}$. at 30 minutes are abnormal.

MEGALOBLASTIC ANAEMIA ASSOCIATED WITH PREGNANCY In 19 patients, the rate of clearance of injected folic acid was abnormally rapid; in the other two patients, the three- and 15- minute levels were within normal limits, while the 30-minute level of $4 \mu \mathrm{mg} . / \mathrm{ml}$. was at the lower limit of normal 
TABLE II

SERUM FOLIC ACID AND SERUM VITAMIN B 12 LEVELS IN PATIENTS WITH MEGALOBLASTIC ANAEMIA ASSOCIATED WITH PREGNANCY

\begin{tabular}{|c|c|c|c|c|}
\hline \multirow{2}{*}{ No. } & \multicolumn{3}{|c|}{ Folic Acid ( $\mu \mathrm{mg} . / \mathrm{ml})}$. & \multirow{2}{*}{$\begin{array}{l}\text { Vitamin } B_{12} \\
(\mu \mu g . / m l .)\end{array}$} \\
\hline & 3 Min. & $15 \mathrm{Min}$. & $30 \mathrm{Min}$. & \\
\hline 1 & 10 & 0 & 0 & 650 \\
\hline 2 & 10 & 1 & 0 & 440 \\
\hline 3 & 12 & 2 & 0 & Contaminated \\
\hline 4 & 21 & 4 & 3 & 430 \\
\hline 5 & 34 & 1 & 0 & 100 \\
\hline 6 & 37 & 0 & 0 & 200 \\
\hline 7 & 39 & 0 & 0 & 370 \\
\hline 8 & 41 & 0 & 0 & 275 \\
\hline 9 & 41 & 0 & 0 & 970 \\
\hline 10 & 44 & 0 & 0 & 1,155 \\
\hline 11 & 46 & 8 & 9 & 130 \\
\hline 12 & 49 & 8 & 3 & 200 \\
\hline 13 & 60 & 8 & 3 & 270 \\
\hline 14 & 65 & 4 & 2 & 150 \\
\hline 15 & 73 & 2 & 0 & 830 \\
\hline 16 & 89 & 14 & 6 & 580 \\
\hline 17 & 113 & 26 & 4 & 230 \\
\hline 18 & 124 & 2 & 2 & 10 \\
\hline 19 & 126 & 29 & 4 & 575 \\
\hline 20 & 156 & 13 & 3 & Contaminated \\
\hline 21 & 250 & 16 & 11 & 250 \\
\hline Mean & 68 & $6 \cdot 5$ & $2 \cdot 4$ & 411 \\
\hline
\end{tabular}

(Table II). In the 19 patients with abnormal clearance patterns, the three-minute level was subnormal in 15 , the 15-minute level subnormal in all, and the 30minute level subnormal in 16. The results are similar to those of Chanarin et al. (1958a) who found rapid clearance of injected folic acid in 11 patients with megaloblastic anaemia of pregnancy.

PERNICIOUS ANAEMIA Fourteen patients showed an abnormally rapid clearance of injected folic acid, while in one patient the three- and 15-minute levels were within normal limits with the 30-minute level at the lower limit of normal (Table III). Of the 14

\section{TABLE III}

SERUM FOLIC ACID AND SERUM VITAMIN B 12 LEVELS IN PATIENTS WITH PERNICIOUS ANAEMIA

\begin{tabular}{ccccc} 
No. & \multicolumn{2}{l}{ Folic Acid $(\mu \mathrm{mg} . / \mathrm{ml})}$. & $\begin{array}{c}\text { Vitamin } \\
(\mu \mu \mathrm{m} . / \mathrm{ml} .)\end{array}$ \\
\cline { 2 - 4 } & 3 Min. & 15 Min. & 30 Min. & \\
\hline 1 & 13 & 0 & 0 & 80 \\
2 & 26 & 10 & 2 & 10 \\
3 & 28 & 0 & 0 & 50 \\
4 & 30 & 0 & 0 & 30 \\
5 & 35 & 0 & 0 & 10 \\
6 & 38 & 0 & 0 & 25 \\
7 & 42 & 0 & 0 & 160 \\
8 & 42 & 2 & 2 & 100 \\
9 & 46 & 18 & 2 & 150 \\
10 & 48 & 10 & 2 & 150 \\
11 & 50 & 3 & 2 & 115 \\
12 & 55 & 48 & 4 & 60 \\
13 & 66 & 13 & 0 & 10 \\
14 & 83 & 3 & 0 & 52 \\
15 & 99 & 23 & 4 & 71 \\
Mean & 47 & 8.6 & $1 \cdot 2$ &
\end{tabular}

patients with abnormal patterns, the three-minute level was subnormal in 13 , the 15-minute level subnormal in 13, and the 30-minute level subnormal in 13.

SCURVY The three subjects with scurvy showed abnormally rapid clearance of injected folic acid from the plasma. The three-, 15-, and 30-minute levels were $30,10,0 \mu \mathrm{mg} . / \mathrm{ml} ., 47,0,0 \mu \mathrm{mg} . / \mathrm{ml}$., and $45,4,1 \mu \mathrm{mg} . / \mathrm{ml}$. respectively.

BANTU MALES In all but two of the healthy Bantu males studied, the serum folic acid levels were above the lower limit of normal. In these two subjects, one showed a subnormal three-minute level, and in one the 15-minute value was subnormal (Table IV).

\section{TABLE IV}

SERUM FOLIC ACID AND SERUM VITAMIN B $B_{12}$ LEVELS IN HEALTHY BANTU MALES AND IN NON-ANAEMIC HOSPITALIZED BANTU FEMALES

\begin{tabular}{|c|c|c|c|c|c|c|}
\hline \multirow[t]{2}{*}{ No. } & \multicolumn{3}{|c|}{$\begin{array}{l}\text { Males } \\
\text { Folic Acid ( } \mu \mathrm{mg} . / \mathrm{ml} .)\end{array}$} & \multicolumn{3}{|c|}{$\begin{array}{l}\text { Females } \\
\text { Folic Acid ( } \mu \mathrm{mg} . / \mathrm{ml} \text {.) }\end{array}$} \\
\hline & 3 Min. & 15 Min. & 30 Min. & 3 Min. & 15 Min. & $30 \mathrm{Min}$ \\
\hline 1 & 64 & 24 & 12 & 17 & 7 & 0 \\
\hline 2 & 80 & 27 & 14 & 78 & 13 & 3 \\
\hline 3 & 95 & 31 & 17 & 103 & 20 & 0 \\
\hline 4 & 115 & 30 & 18 & 104 & 25 & 13 \\
\hline 5 & 195 & 38 & 19 & 125 & 21 & 11 \\
\hline 6 & 225 & 32 & 19 & 168 & 38 & 24 \\
\hline 7 & 240 & 11 & 9 & 190 & 19 & 1 \\
\hline 8 & 250 & 61 & 44 & 248 & 53 & 4 \\
\hline Mean & 153 & 31 & 19 & 129 & 27 & 9 \\
\hline
\end{tabular}

BANTU FEMALES In four of the group of eight nonanaemic Bantu females the clearance pattern was abnormal (Table IV). In one subject the three-, 15-, and 30-minute folic acid levels were all subnormal and three others showed subnormal 30minute levels.

\section{DISCUSSION}

The serum folic acid levels after intravenous injection of folic acid in the normal subjects studied are similar to those reported by Chanarin et al. (1958a). There is a clear difference in the folic acid levels in normal subjects and in patients with megaloblastic anaemia, the 15- and 30-minute levels providing the most significant differences. The folic acid clearance test will therefore establish deficiency of folic acid where the deficiency is severe enough to produce megaloblastic anaemia.

The rapid clearance of injected folic acid in a significant number of Bantu females not suffering from anaemia confirms that the test is able to establish folic acid deficiency before the development 
of anaemia, and suggests that subclinical folic acid deficiency is not uncommon in this group. In the Bantu males studied, the clearance pattern is more similar to that of normal Whites, and correlates with the observation that megaloblastic anaemia due to primary folic acid deficiency is rarely seen in this group (Metz, 1960).

Rapid clearance of injected doses of folic acid in patients with scurvy possibly indicates that in human scurvy there is an associated dietary deficiency of folic acid, resulting in depletion of body folic acid stores. It has been shown that folic acid deficiency with megaloblastic anaemia regularly develops in scorbutic monkeys fed on a milk diet (May, Hamilton, and Stewart, 1952).

The finding of rapid clearance of injected doses of folic acid in severely anaemic patients with primary viatmin $\mathbf{B}_{12}$ deficiency (pernicious anaemia) confirms the observations of Chanarin et al. (1958a). The folic acid clearance test is thus unable to distinguish megaloblastic anaemia due to primary $B_{12}$ deficiency from that due to primary folic acid deficiency. These findings can be explained on the basis that deficiency of vitamin $B_{12}$ may condition body deficiency of folic acid, the rate of clearance of injected folic acid in patients with primary vitamin $B_{12}$ deficiency being then an index of the degree of depletion of folic acid in these patients. Secondary folic acid deficiency in patients with primary $B_{12}$ deficiency would also explain the finding of FIGLU in the urine in $B_{12}$ deficiency (unpublished observations quoted by Herbert et al., 1960) and suggests that any test of folic acid deficiency would be unable to distinguish between primary folic acid deficiency and that conditioned by vitamin $\mathbf{B}_{12}$ deficiency. Secondary folic acid deficiency can be demonstrated in experimentally produced vitamin $\mathbf{B}_{12}$ deficiency in sheep (Dawbarn, Hine, and Smith, 1958). That the converse may apply, i.e., vitamin $\mathrm{B}_{12}$ deficiency conditioned by primary folic acid deficiency, is suggested by the subnormal levels of serum vitamin $B_{12}$ in some patients with megaloblastic anaemia associated with pregnancy. In these patients, however, vitamin $\mathrm{B}_{12}$ deficiency may be occurring pari passu with that of folic acid.

We wish to thank the Director, South African Institute for Medical Research, for providing the facilities for this study, Lederle Laboratories for a grant towards some of the expenses, and Dr. I. Chanarin, St. Mary's Hospital, London, for considerable help and advice.

\section{REFERENCES}

Brandt, V., and Metz, J. (1961). S. Afr. J. med. Sci., 26, 1.

Broquist, H. P. (1956). J. Amer. chem. Soc., 78, 6205.

Broqu and Luhby, A. L. (1959). Proc. Soc. exp. Biol. (N.Y.), 100, 349.

Callender, S. T., and Denborough, M. A. (1957). Brit. J. Haemat., 3, 88.

Chanarin, I. (1958). Brit. med. J., 1, 1179.

-, Anderson, B. B., and Mollin, D. L. (1958b). Brit. J. Haemat., $4,156$.

-, Mollin, D. L., and Anderson, B. B. (1958a). Ibid, 4, 435. MacGibbon, B. M., O'Sullivan, W. J., and Mollin, D. L. (1959). Lancet, $2,634$.

Cooperman, J. M., Luhby, A. L., and Avery, C. M. (1960). Proc. Soc. exp. Biol. (N.Y.), 104, 536.

Davidson, C. S., and Jandl, J. H. (1959). Amer. J. clin. Nutr., 7, 711.

Dawbarn, M. C., Hine, D. C., and Smith, J. (1958). Aust. J. exp. Biol. med. Sci., 36, 541.

Herbert, V., Baker, H., Frank, O., Pasher, I., Sobotka, H., and Wasserman, L. R. (1960). Blood, 15, 228.

Jukes, T. H. (1955). In Meth. biochem. Anal., 2, 121.

Luhby, A. L. (1957). Clin. Res. Proc., 5, 8.

May, C. D., Hamilton, A., and Stewart, C. T. (1952). Blood, 7, 978.

(1959). M.D. Thesis, University of Witwatersrand.

Metz, J. (1960). Proc. VIIth int. Congr. int. Soc. Hemat., Rome, 1958, Vol. 2, p. 339.

Silverman, M., Gardiner, R. C., and Condit, P. T. (1958). J. nat. Cancer Inst., 20, 71.

Spray, G. H., Fourman, P., and Witts, L. J. (1951). Brit. med. J., 2, 202.

- , and Witts, L. J. (1959). Lancet, 2, 702. 